\title{
Economic impacts of El Niño southern oscillation: evidence from the Colombian coffee market
}

\author{
Andrea Bastianin $^{\mathrm{a}, *}$, Alessandro Lanza ${ }^{\mathrm{b}, \mathrm{c}}$, Matteo Manera ${ }^{\mathrm{d}, \mathrm{e}}$ \\ ${ }^{a}$ University of Milan, Milan, Italy \\ ${ }^{\mathrm{b}}$ LUISS University, Rome, Italy \\ ${ }^{\mathrm{c}}$ Euro-Mediterranean Center on Climate Change, Bologna, Italy \\ ${ }^{\mathrm{d}}$ University of Milan-Bicocca, Milan, Italy \\ ${ }^{\mathrm{e}}$ Fondazione Eni Enrico Mattei, Milan, Italy
}

Received 20 March 2017; received in revised form 30 March 2018; accepted 10 May 2018

\begin{abstract}
El Niño Southern Oscillation (ENSO) is a naturally occurring phenomenon that affects weather around the world. Past ENSO episodes have had severe impacts on the economy of Colombia. We study the influence of ENSO on Colombian coffee production, exports, and price. Our structural econometric specification is consistent with an economic model of the market for Colombian coffee which, in the short run, is characterized by a downward-sloping demand curve and by a vertical supply curve. We show that El Niño (i.e., positive shocks to ENSO) is beneficial for Colombian production and exports and decreases the real price of Colombian coffee. On the contrary, La Niña (i.e., negative shocks to ENSO) depresses Colombian coffee production and exports and increases price. However, the overall impact of ENSO shocks is small. Both in the short run and in the long run, shocks to international demand for Colombian coffee are more relevant than supply-side shocks in Colombia in explaining the dynamics of the price of Colombian coffee. Our results suggest that a given coffee price shock can have beneficial, detrimental, or negligible effects on the Colombian economy, depending on its underlying cause. As a consequence, policy responses to coffee price shocks should be designed by looking at the causes of the shocks.
\end{abstract}

JEL classifications: C32, O13, Q02, Q11, Q54

Keywords: Coffee; Colombia; El Niño; ENSO; La Niña; Structural VAR

\section{Introduction}

El Niño Southern Oscillation (ENSO) is a naturally occurring phenomenon that changes the global atmospheric circulation and affects sea-level pressure, sea-surface temperatures (SSTs), precipitation, and winds around the globe. The socioeconomic impacts of weather fluctuations have been widely investigated (see Dell et al., 2014, for a survey). ENSO events and, more generally, temperature and precipitation anomalies are associated with lower economic growth rates, agricultural yields and fishery (Dell et al., 2012; Hsiang and Meng, 2015; Iizumi et al., 2014; Sun et al., 2006; Tack and Ubilava, 2015), commodity price inflation (Brunner, 2002; Cashin et al., 2017; Ubilava, 2018), and effects on human health (Andalón et al., 2016).

This article addresses the question of how ENSO anomalies affect production, exports, and real price of Colombian Arabica

*Corresponding author. Tel.: +003902 50321 530; fax: +00390250321 505. E-mail address: andrea.bastianin@unimi.it (A. Bastianin). coffee. Although in recent years the importance of the coffee industry for the Colombian economy has decreased, it remains an important source of employment and contributes to stability and prosperity of the rural areas of the country (Dube and Vargas, 2013; Miller and Urdinola, 2010). ${ }^{1}$ Colombia is a leading producer of top-quality Arabica coffee and has a shore on the equatorial Pacific, therefore its economy is particularly sensitive to ENSO anomalies. Hoyos et al. (2013) point out that, due to flooding, destruction of infrastructures and payment of government subsidies, the 2010-2011 La Niña caused losses for more than U.S. $\$ 7.8$ billion, while the drought following the 1997-1998 El Niño determined a 10\% drop in coffee production (Poveda et al., 2001). Moreover, because of the negative impact

\footnotetext{
${ }^{1}$ In 2014, Colombia's top exports were crude petroleum (45\%), coal briquettes $(13 \%)$, refined petroleum products $(4.9 \%)$, and coffee $(4.7 \%)$. In 1990, Colombia exported mainly crude petroleum (24\%), coffee (23\%), and bananas (6.8\%). In 1980, coffee represented 59\% of total exports. Source: http://atlas.media.mit.edu/en/ The Economic Complexity Observatory.
} 
on many agricultural commodities, Colombia was forced to import more than 3.5 million tons of grains and other food supplies. La Niña of 2007-2008 has been one of the main factors contributing to the outbreak of the "coffee rust" (Avelino et al., 2015). Between 2008 and 2011, this orange-colored fungusalso known as "la roya" - ravaged coffee plantations in Southern and Central America, causing Colombian production to drop in 2009 by $31 \%$ compared to the level of 2008 .

The main novelty of this article is to present a structural econometric model for the Colombian coffee market that allows to identify the effects of ENSO anomalies, while controlling for shocks arising from both the supply side and the demand side of the Colombian and world coffee markets. We posit that the real price of Colombian coffee is jointly determined by shocks to the Colombian coffee supply, shocks arising in the world coffee market, Colombian export policy shocks (e.g., due to export retention schemes, quotas, or "quality initiatives" 2 , and El Niño (La Niña) anomalies. In this way, we are able to isolate the impacts of extreme ENSO events from shocks to economic fundamentals. Other studies on the "ENSO-commodity price inflation" nexus do not control for supply and demand shocks, although they are expected to be the main drivers of the real prices of coffee and of other commodities (Ubilava, 2012, 2018). Moreover, most studies model and forecast the price of coffee with reduced form specifications that cannot identify the causes underlying coffee price shocks (see Ghoshray, 2010; Vogelvang, 1992). Our econometric model also relates to the strand of the literature dealing with the macroeconomic effects of coffee price shocks. Some of these studies focus only on price shocks originating from the supply side, thus neglecting the importance of demand-driven price shocks (Dube and Vargas, 2013; Miller and Urdinola, 2010). In other cases, the cause of a given price shock is not explicitly identified (Otero, 2001; Raju and Melo, 2003) and the price of coffee is treated as exogenous (Edwards, 1984). However, since there are no reasons to expect that a coffee price shock, driven by a shortfall to local production, might have the same impacts as a price shock driven by an export boom, our model could be used to improve our understanding of the linkages between the price of Colombian coffee and the economy of this country.

We show that during El Niño Colombian production and exports increase, while the real price of Colombian coffee decreases. On the contrary, the development of La Niña depresses Colombian coffee production and exports, while boosting its real price. The overall impact of ENSO shocks is small. In the short run, ENSO shocks explain $2.2 \%$ of the fluctuations of Colombian coffee production and $0.2 \%$ of the variability of the real price of Colombian coffee. In the long run, these percentages are $8.3 \%$ and $5.8 \%$, respectively. Both in the short run and in the long run, shocks to Colombian coffee supply explain on their own only a small fraction of the variability of Colombian

\footnotetext{
${ }^{2}$ With these interventions, low-quality coffee is withdrawn from the market with the aim of increasing the value of exported coffee by increasing the overall export quality (see, e.g., chapter 7 in Daviron and Ponte, 2005).
}

coffee prices, which is instead mostly accounted for by shocks arising in the world market for coffee.

The rest of the article is organized as follows. Section 2 provides a background on the ENSO cycle and the Colombian coffee industry. Data and econometric methods are described in Section 3, while the main results are presented in Section 4. Policy implications are discussed in Section 5, which also concludes the article.

\section{ENSO and the Colombian coffee industry}

ENSO describes the interaction between atmosphere and ocean in the tropical Pacific region, which influences climate patterns worldwide. "El Niño" refers to the ocean component of ENSO (i.e., the cycling of SSTs between below- and abovenormal), while the "Southern Oscillation" (SO) captures largescale fluctuations in air pressure (i.e., the atmospheric component of ENSO). ENSO is thus a single natural climate phenomenon with three distinct phases: El Niño, La Niña, and a neutral state, where the atmosphere and ocean conditions are close to their long-term average. El Niño is the warm phase of the ENSO cycle, characterized by higher-than-usual sea temperatures in the central and eastern equatorial Pacific Ocean. It is also the negative phase of the SO, when abnormally high air pressure covers Indonesia and abnormally low air pressure characterizes the east-central tropical Pacific. El Niño is often followed by La Niña, which is characterized by cooler-thanusual sea water in the equatorial Pacific Ocean. La Niña is the cold phase of ENSO and the positive phase of the SO, when abnormally low air pressure covers Indonesia and abnormally high air pressure covers the east-central tropical Pacific. ${ }^{3}$

Although climatologists have made substantial progresses in modeling ENSO and can now predict the arrival of its warm and cold phases months in advance (see, e.g., Chen et al., 2004), past El Niño and La Niña episodes have had severe impacts on the Colombian economy (Hoyos et al., 2013; Poveda et al., 2001), which is largely dependent on the production of high-quality Arabica coffee (Ubilava, 2012, 2018). During the 2014-2015 marketing year, Brazil, Vietnam, and Colombia accounted, respectively, for $35.4 \%, 17.9 \%$, and $8.7 \%$ of world coffee production. While Brazil and Vietnam produce both Robusta and Arabica coffee, Colombia only supplies high-quality Arabica varieties. In terms of Arabica production, Colombia is second only to Brazil. ${ }^{4}$ However, Brazilian varieties, produced on a massive scale at low altitudes and harvested mechanically, are perceived to be of lower in quality than Colombian coffee,

\footnotetext{
${ }^{3}$ For more details, see World Meteorological Organization (2014) and the ENSO Resources web page of the International Research Institute for Climate and Society, available online at http://iri.columbia.edu.

${ }^{4}$ Robusta represents $96 \%$ (31\%) of total production in Vietnam (Brazil), although yields beans of inferior quality than Arabica (Ghoshray, 2010). Focusing only on Arabica, the three largest producers in 2014-2015 were Brazil (43.1\%), Colombia (15.4\%), and Ethiopia (7.5\%). Source: U.S. Department of Agriculture.
} 
which is harvested by hand all year round at higher altitudes on the foothills of the Andes (Café de Colombia, 2017). Several factors, such as climatic conditions and weather patterns; physical and chemical characteristics of the soil, latitude, and altitude of the growing zones; and the low degree of mechanization, contribute to the perceived high quality of Colombian coffee and explain its price premium over other coffee varieties, such as Robusta. ${ }^{5}$

\section{Data and methods}

\subsection{Data}

We estimate a Structural Vector Autoregressive (VAR) model that includes four variables sampled monthly over the January 1990-May 2016 period, for a total of 317 observations. ${ }^{6}$ Economic impacts of ENSO are measured through SST anomalies $\left(s s t_{t}\right)$. This variable, sourced from the U.S. National Oceanic and Atmospheric Administration, represents deviations from the seasonal mean of SSTs, hence it is a natural proxy of weather anomalies due to ENSO. El Niño and La Niña are episodes with five consecutive three-month running mean of SST anomalies in the so-called "Niño 3.4 region" above (below) the threshold of $+0.5^{\circ} \mathrm{C}\left(-0.5^{\circ} \mathrm{C}\right)$.

Colombian coffee production, exports (both expressed in thousands of bags of $60 \mathrm{~kg}$ green bean equivalent), and the external price of Colombian coffee (expressed in nominal U.S. cents per pound) are provided by the Colombian Coffee Growers Federation. We obtain the real price of Colombian coffee (expressed in May 2016 U.S. dollars per pound) by deflating the nominal price using the U.S. Consumer Price Index sourced from the Federal Reserve Bank of St. Louis. The model includes the percentage first-difference of log production $\left(\Delta \operatorname{prod}_{t}\right), \log$ exports $\left(\exp _{t}\right)$, and $\log$ real price $\left(r p c_{t}\right)$, with the latter two variables expressed in percentage deviations from their sample averages. ${ }^{7}$ We rely on log production in first-differences because

\footnotetext{
${ }^{5}$ More specifically, Arabica coffee can be further divided into Colombian Milds, Brazilian Naturals, and Other Milds. Since Colombian Milds are considered to be of the highest quality, they are sold at a premium over the price of the other types of coffee. During the 1990-2015 period, the average prices of Colombian Milds, Other Milds, Brazilian Naturals, and Robusta coffee were, respectively, 135.0, 127.2, 112.4, and 72.4 U.S. cents per pound (International Coffee Organization).

${ }^{6}$ As shown by Cárdenas (1994), over the 1961--1988 period in Colombia the National Federation of Coffee Growers, through the administration of the National Coffee Fund, has been successful in achieving domestic price stabilization and hence in influencing production decisions by farmers. Thus, although data are available starting from the late 1950s, the estimation sample begins in January 1990, since, before 1990, the price of coffee was regulated under the International Coffee Agreement (ICA) regime. The first ICA was signed in 1962 by most consuming and producing countries with the aim of stabilizing the price of coffee. Under the ICA regime, a target price (or price band) was set and export quotas were allocated to each coffee producer. The ICA failed to be renewed in July 1989 (Ponte, 2002).

${ }^{7}$ While expressing these variables in deviations from the sample averages is inconsequential for the robustness empirical results, this transformation facilitates the interpretation of the historical decompositions.
}

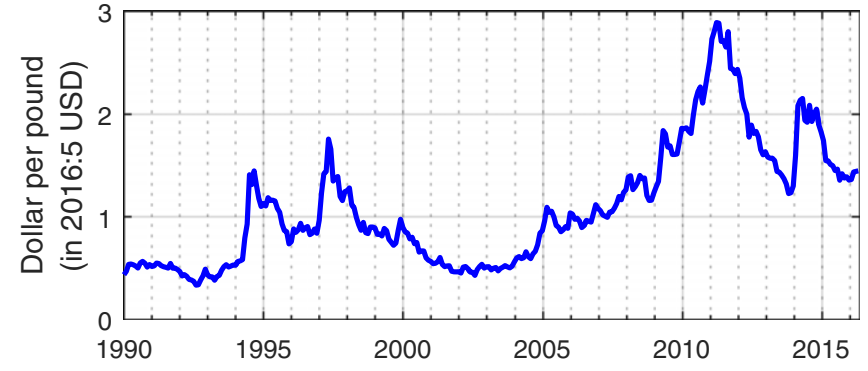

Source: Colombian Coffee Growers Federation $\left(P C_{t}\right)$ and Federal Reserve Bank of St. Louis $\left(C P I_{t}\right)$.

Notes: The real price of coffee $\left(R P C_{t}\right)$, expressed in 2016:5 U.S. \$ per pound, has been obtained by deflating the nominal price $\left(P C_{t}\right)$ using the Consumer Price Index $\left(C P I_{t}\right): R P C_{t} \equiv P C_{t} \times\left(C P I_{t} / C P I_{2016: 5}\right)$.

Fig. 1. Real price of Colombian coffee: January 1990-May 2016. [Color figure can be viewed at wileyonlinelibrary.com]

the growth rate of production is tightly linked with the notion of production shortages, which are often seen as the main drivers of commodity price shocks. Therefore, in our model, Colombian coffee supply shocks correspond to unpredictable changes in the growth of coffee production. Price and exports are in log levels and have not been differenced, since economic theory suggests a link between cyclical fluctuations in demand and the real price of Colombian coffee (Erten and Ocampo, 2013). First-differencing would remove their low-frequency covariation, making it virtually impossible to analyze how shocks to demand accumulate over time and affect the real price of Colombian coffee.

Fig. 1 shows that the real price of Colombian coffee is highly volatile. This fact is consistent with a low price elasticity of supply, and low price and income elasticities of demand that jointly tend to magnify the price impact of actual and expected supply shortages (Mehta and Chavas, 2008; Ponte, 2002). With the exception of few spikes in the 1990s due to frosts in Brazil, the real price of Colombian coffee has remained at very low levels from 1990 to 2004. During this period, which includes the coffee crisis, the world coffee market was oversupplied due to rising production from Brazil, Vietnam, and other Asian countries and a relatively weak growth in world demand for coffee. Moreover, the failure of the ICA in 1989, which encouraged member countries to stockpile coffee surpluses in order to keep prices high, is another reason for such low prices (Osorio, 2002). This period is followed by a price rally that lasted until 2011 . Over the years 2004-2011, the coffee market was characterized by a tight balance between supply and demand, exacerbated by low level of stocks in producing countries. Coffee production was also severely affected by the development of plant diseases and unfavorable weather conditions in Colombia, Brazil, and other producing countries. With this respect, the price decrease observed from 2011 onward is simply due to production recovering from the damages caused by the coffee rust. ${ }^{8}$ This

\footnotetext{
${ }^{8}$ The dynamics of the price of coffee is reconstructed from the reading of various releases of the International Coffee Organizations Annual Review. This
} 
summary description shows that at each point in time, the real price of Colombian coffee is hit by a multitude of shocks that jointly shape its dynamics.

\subsection{The econometric model}

We can write the reduced form of a VAR(24) model for $\mathbf{y}_{t} \equiv\left[s s t_{t}, \Delta \operatorname{prod}_{t}, r p c_{t}, \operatorname{cexp}_{t}\right]^{\prime}$ as follows:

$\mathbf{y}_{t}=\boldsymbol{\mu}_{t}+\sum_{j=1}^{24} \mathbf{A}_{j} \mathbf{y}_{t-j}+\mathbf{e}_{t}$

where $\boldsymbol{\mu}_{t}$ includes a constant and seasonal dummies (i.e., month-of-the-year dummies), $\mathbf{A}_{j}$ for $j=1, \ldots, 24$ are matrices of parameters and $\mathbf{e}_{t}$ is a vector of reduced form errors. From now on, we ignore the vector of deterministic regressors, $\boldsymbol{\mu}_{t}$; this does not alter the presentation, but facilitates the notation. The structural form of the model is:

$\mathbf{B}_{0} \mathbf{y}_{t}=\sum_{j=1}^{24} \mathbf{B}_{j} \mathbf{y}_{t-j}+\boldsymbol{\varepsilon}_{t}$

where $\mathbf{B}_{j}$ for $j=0, \ldots, 24$ are matrices of structural parameters and $\boldsymbol{\varepsilon}_{t}$ is a vector of serially and mutually uncorrelated structural errors. The matrix $\mathbf{B}_{0}$ collects the parameters governing the contemporaneous relations between our endogenous variables. The reduced form of the VAR model is obtained by pre-multiplying Eq. (2) by the inverse of $\mathbf{B}_{0}$, denoted as $\mathbf{B}_{0}^{-1}$, and known as "structural impact multiplier matrix." Similarly, reduced form VAR errors, $\boldsymbol{e}_{t}$, are given by $\mathbf{e}_{t}=\mathbf{B}_{0}^{-1} \boldsymbol{\varepsilon}_{t}$.

\subsection{Model specification and estimation}

Reduced-form parameters in Eq. (1) are estimated by least squares (LS), while structural-form parameters and shocks are recovered relying on a Cholesky decomposition of the reducedform residual covariance matrix. ${ }^{9}$

The strategy of including two variables expressed in log levels $\left(\operatorname{cexp}_{t}, r p c_{t}\right)$ and one in first-difference $\left(\Delta \operatorname{prod}_{t}\right)$ in the block of the model for the Colombian coffee market, as well as the choice of using a VAR with 24 lags can be justified on the basis of several economic and econometric considerations. First, as illustrated at the beginning of this section, we use log production in first-differences because the growth rate of Colombian production is tightly linked with production shortages. On the contrary, Colombian coffee price and exports are in log levels, since

description has also substantially benefited from the contributions of Daviron and Ponte (2005) and Pendergrast (1999), which have been brought to our attention by an anonymous referee. Additional details about the data, graphs, and descriptive statistics are shown in Section A of the Appendix in Supporting Information.

${ }^{9}$ More details about estimation and implementation are discussed in Section B of the Appendix in Supporting Information(see Amisano and Giannini, 1997; Hamilton, 1994; Kilian and Lütkepohl, 2017, for further details). first-differencing would remove their low-frequency covariation and make it difficult to analyze how shocks to the demand for Colombian coffee accumulate over time and affect the real price of coffee in Colombia. Second, our structural VAR model is identified by means of short-run restrictions only. Within this framework, cointegration, which would imply additional longrun restrictions, has been considered as not necessary to our analysis. Third, in our baseline VAR model with 24 lags the largest estimated autoregressive root is 0.981 . When data are highly persistent, unit-root and stationarity tests are known to have very low power (see, e.g., Cochrane, 1991). Moreover, if the dominant root is local-to-unity, the use of these tests as a tool for model selection is invalid (Cavanagh et al., 1995). These "pre-test" biases extend also to models based on cointegration tests (Elliott, 1998). Fourth, while imposing unit-root and cointegration restrictions into a VAR might improve the efficiency of impulse response estimators, impulse responses can be consistently estimated also running the VAR in levels and without imposing such restrictions (Sims et al., 1990). Fifth, imposing unit-root and cointegration restrictions that are not supported by the data would deliver inconsistent LS coefficients estimates and hence inconsistent impulse response estimates (Kilian and Lütkepohl, 2017). Sixth, Gospodinov et al. (2013) show that, in case of doubt on the integration properties of the series, the level specification is preferable. Seventh, Toda and Yamamoto (1995) show that if a $\operatorname{VAR}(p)$ model includes variables that are integrated of order $d$ standard asymptotic results apply, provided that the model includes $d$ extra lags. Bauer and Maynard (2012) extend this result to VAR processes with local-to-unity roots, long memory and known structural breaks. This lagaugmentation procedure clearly leads to a loss of efficiency and inflates the width of confidence intervals for IRFs. However, if the lag order is too low, misleading estimates and inference can occur (see, e.g., Hamilton and Herrera, 2004). Eighth, as pointed out by Kilian (2009) and Kilian and Lütkepohl (2017), long lags are necessary when studying commodity prices that typically exhibit very long cycles. As shown by Erten and Ocampo (2013), in the case of nonoil commodity prices, these cycles depend essentially on demand-side drivers; therefore a VAR model with few lags would miss slowly building price movements associated with gradual changes in demand. Finally, coffee production involves long delays between planting, cropping, harvesting, and marketing (e.g., it takes at least two years before new coffee trees begin to bear fruits; see Ponte, 2002). In particular, Arabica coffee trees are characterized by a "biennial bearing cycle," that is a high-production year alternates with a low-production year (ICO, 2014; Terazono, 2013; Wegmann, 2013; Wickens and Greenfield, 1973).

Our results are robust to a number of modifications of the baseline empirical specification, such as changes in the VAR lag order and different empirical proxies for ENSO. ${ }^{10}$

\footnotetext{
${ }^{10}$ See Section D of the Appendix in Supporting Information for details.
} 


\subsection{Identification}

Model identification is achieved by imposing the following set of exclusion restrictions on $\boldsymbol{B}_{0}^{-1}$ :

$$
\left(\begin{array}{l}
e_{t}^{s s t} \\
e_{t}^{\Delta p r o d} \\
e_{t}^{r p c} \\
e_{t}^{\text {cexp }}
\end{array}\right)=\left[\begin{array}{llll}
b_{11} & 0 & 0 & 0 \\
b_{21} & b_{22} & 0 & 0 \\
b_{31} & b_{32} & b_{33} & 0 \\
b_{41} & b_{42} & b_{43} & b_{44}
\end{array}\right]\left(\begin{array}{l}
\varepsilon_{t}^{\text {ENSO }} \\
\varepsilon_{t}^{\text {Colombian coffee supply }} \\
\varepsilon_{t}^{\text {World coffee market }} \\
\varepsilon_{t}^{\text {Colombian export policy }}
\end{array}\right)
$$

This model focuses on the main forces driving the real price of Colombian coffee in the short run, namely shocks to Colombian supply, shocks arising in the world coffee market, and Colombian export policy shocks. The presence of zeros (i.e., exclusion restrictions) in system (3) can be motivated as follows. An "ENSO shock" is defined as an unpredictable change of $s s t_{t}$. Positive ENSO shocks identify unpredictable El Niño events, while unpredictable negative changes of $s s t_{t}$ represent La Niña episodes. Consistently with the identification approaches of Brunner (2002) and Cashin et al. (2017), our identification scheme implies that an ENSO shock affects the production, exports, and the real price of Colombian coffee within the same month, but not vice versa. Without further restrictions, this means that ENSO shocks affect Colombian coffee supply, the world market for coffee, and Colombian coffee exports. Our model is linear and hence it implicitly assumes that the responses of Colombian coffee price, production, and exports to positive and negative ENSO shocks are symmetric (i.e., the responses change sign, but are of the same magnitude). Moreover, it also implies that the timing of the responses to negative and positive ENSO shocks is the same.

Innovations to Colombian coffee production not explained by ENSO shocks are referred to as "Colombian coffee supply shocks." Our model assumes that the supply of Colombian coffee does not respond, on impact, neither to shocks arising in the world market for coffee, nor to Colombian export policy interventions. This is in line with theoretical models for the coffee market that assume a vertical coffee supply (Mehta and Chavas, 2008; Wickens and Greenfield, 1973). Low empirical estimates of short-run supply elasticity can be reconciled with the fact that it takes years before new trees start bearing coffee beans and reach full productivity (Ghoshray, 2010; Ponte, 2002). On the contrary, a shortage due to ENSO-related weather events leads to an immediate change in Colombian coffee supply. Similarly, Colombian coffee supply changes on impact in response to the spread of plant diseases, or to weather shocks that are not associated with ENSO.

Innovations to the international price of Colombian coffee that are not explained by the outbreak of ENSO shocks, nor by shocks to the Colombian coffee supply, are called "world coffee market shocks." The zero restriction in the third row of system (3) implies that the international price of Colombian coffee responds on impact to everything that happens in the world market for coffee, with the exception of innovations to Colombian exporting decisions. Specifically, the third shock captures production shortfalls in countries producing Arabica and other coffee varieties, changes to consumer demand for Colombian and any other kind of coffee, and changes to stock accumulation by managers managing warehouses for Colombian Arabica and every other variety of coffee. This zero restriction is consistent with a "small country assumption" (see, e.g., Cushman and Zha, 1997) and is justified by the fact that after the failure of the ICA individual producing countries have largely lost control over their coffee prices (Daviron and Ponte, 2005; Ponte, 2002).

Finally, changes to Colombian coffee exports not explained by innovations to ENSO, Colombian supply, or world coffee market shocks are referred to as "Colombian export policy shocks" and capture policy interventions aimed at altering the international price of Colombian coffee, such as export retention schemes, quotas or "quality initiatives." In turn, this implies that Colombian exports immediately respond to all events affecting the Colombian and the world markets for coffee.

\section{Empirical results}

\subsection{Impulse response analysis}

Figs. 2 and 3 present the response of the Colombian production, exports, and real price of coffee to a one standard deviation shock to ENSO, Colombian coffee supply, and Colombian export policy, as well as to innovations arising in the world coffee market. Each panel shows the estimated impulse response function (IRF), as well as one and two standard error bands (namely, $68 \%$ and $95 \%$ confidence intervals), based on a recursive-design wild bootstrap with 2,000 replications (see Gonçalves and Kilian, 2004).

\subsubsection{The impacts of El Niño on the Colombian coffee market}

In Fig. 2, we focus on the IRF generated by a positive ENSO shock that, being an unpredictable positive change in SST anomalies, signals the outbreak of El Niño conditions. In the coffee-growing zones of Colombia, El Niño tends to increase temperatures and sunlight and to decrease rainfalls and soil moisture (Poveda et al., 2001). These factors stimulate the growth and flowering of coffee trees, with a positive impact on production (Café de Colombia, 2014). Fig. 2 confirms that a positive ENSO shock has beneficial impacts on Colombian production and exports. The outbreak of El Niño yields a temporary, although long lived, increase in Colombian coffee production and exports. The IRF of production becomes statistically significant at the $95 \%$ confidence level with a delay of at least 12 months. Then, it remains statistically significant, at the $68 \%$ confidence level, up to 21 months after the positive ENSO shock.

The bottom panel of Fig. 2 shows that the response of Colombian exports to ENSO shocks is further delayed. The IRF becomes statistically significant at the $95 \%$ confidence level only after 16 months, but five months later it is no more statistically 

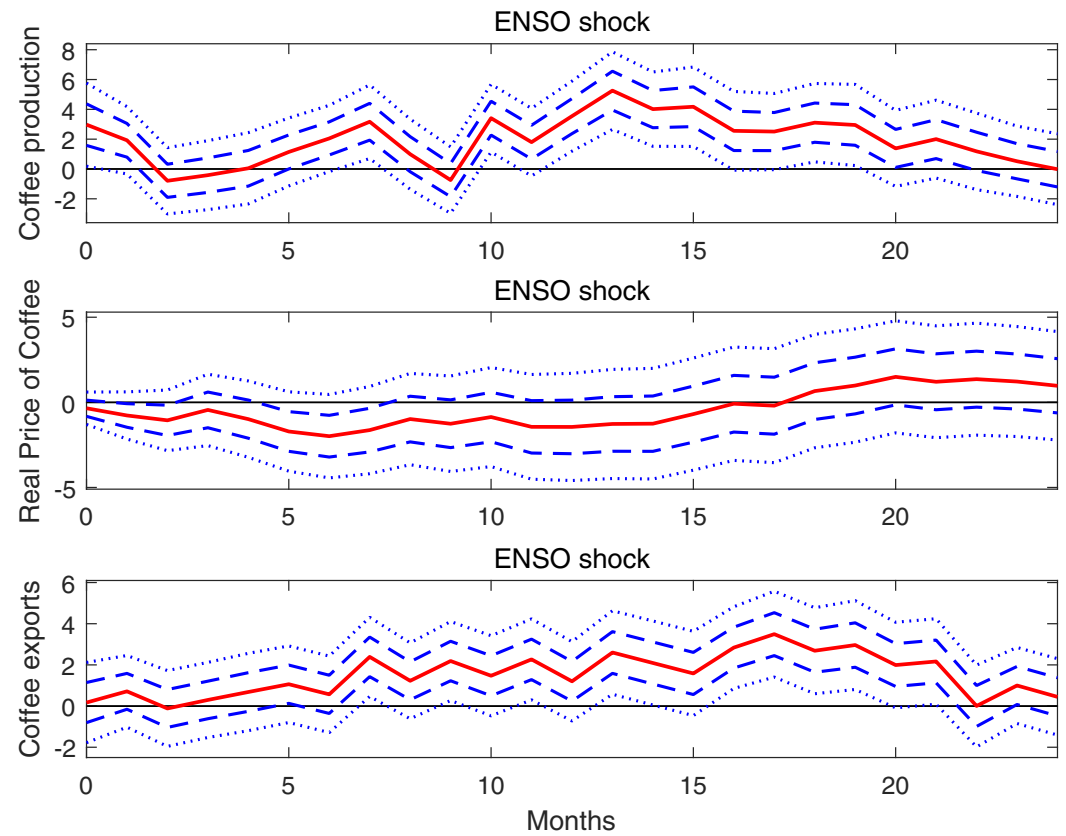

Notes: Impulse responses to a one standard deviation ENSO (sea-surface temperature, or SST, anomalies) shock (continuous line), with one and two standard error bands (dashed and dotted lines, respectively) from the estimation of the structural VAR model with 24 lags described in Section 3, using monthly data over the period January 1990-May 2016.

Fig. 2. Impulse responses to a positive ENSO shock. [Color figure can be viewed at wileyonlinelibrary.com]
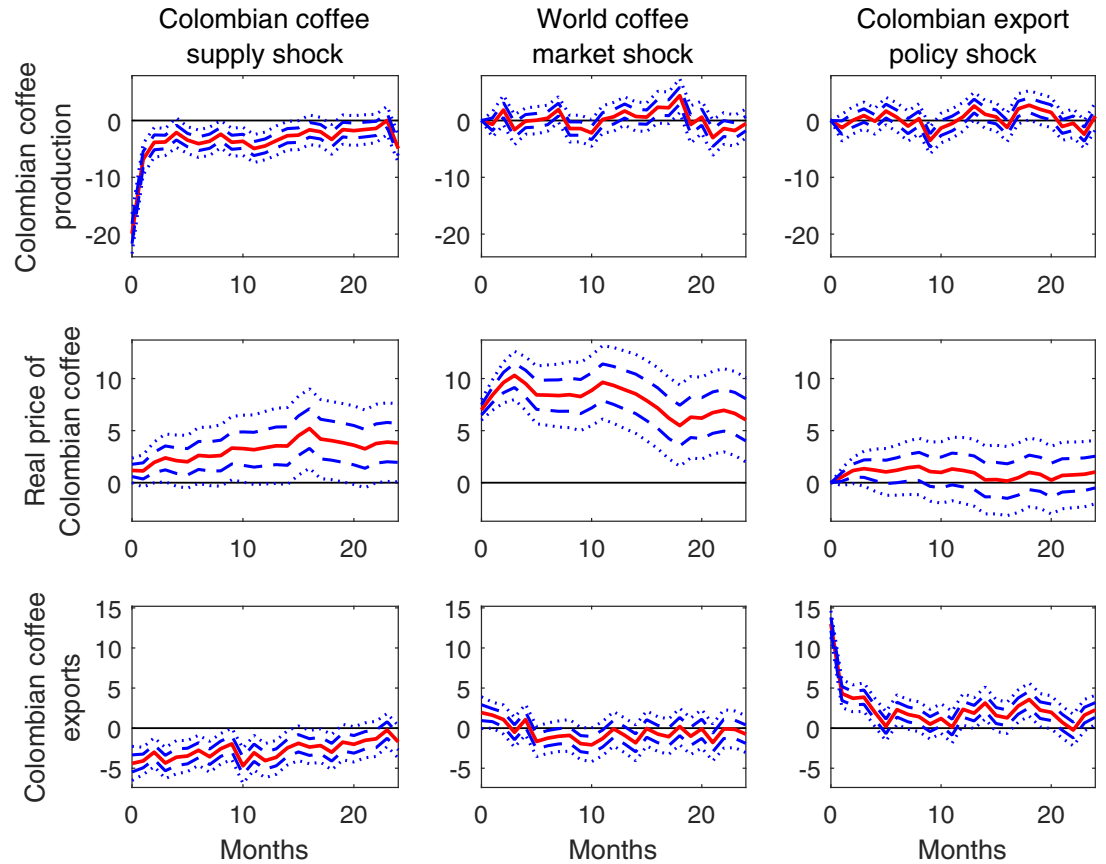

Notes: Impulse responses to one standard deviation structural shocks (continuous line), with one and two-standard error bands (dashed and dotted lines, respectively) from the estimation of the structural VAR model with 24 lags described in Section 3, using monthly data over the period January 1990-May 2016.

Fig. 3. Impulse responses for the Colombian coffee market. [Color figure can be viewed at wileyonlinelibrary.com] 
distinguishable from zero. The behavior of these responses is explained by the fact that any impact of ENSO on Colombian production and exports must incorporate the delays characterizing the coffee production cycle. The result that a positive ENSO surprise leads to an increase in Colombian coffee exports might be rationalized by the geographical variability of its effects (see, e.g., Cashin et al., 2017; Iizumi et al., 2014). Therefore, the rise in Colombian exports might serve to compensate an El Niño-driven production shortfall recorded in other countries (Ubilava, 2012).

The panel in the middle of Fig. 2 displays the response of the real price of Colombian coffee to a positive ENSO surprise. On average, over the 1990-2016 period, the development of El Niño has led to a reduction of the real price of Colombian coffee that lasts up to 16 months after the shock. However, the IRF of the real price is negative and statistically significant only using the $68 \%$ confidence bands and in the first semester following the ENSO surprise. The price-depressing effects of El Niño can be reconciled with the fact that El Niño has two positive impacts, one on the production of coffee in Colombia and the second on its exports. In the presence of a vertical supply, which of the two effects prevails will depend on the price elasticity of demand. In the case of coffee, the short-run price elasticity of both demand and supply is low (Mehta and Chavas, 2008; Ponte, 2002), therefore the price decrease due to the "supply effect" might dominate the price increase due to the "export effect."

Our model is linear, that is, it does not take into account nonlinear or asymmetric responses; this characteristic implies that to gauge the effects of a negative ENSO surprise (i.e., La Niña), the IRFs of production, exports, and the real price of coffee should be simply translated on the horizontal axis. Hence, following the outbreak of La Niña, Colombian coffee production and exports decrease, while the real price of Colombian coffee increases. During La Niña, temperatures and sunlight decrease and rainfalls and soil moisture increase (Poveda et al., 2001). The complex interaction of these conditions lower the productivity of Colombian coffee plantations and boosts the hazard of plant diseases and floods. Notwithstanding different geographical impacts of ENSO, La Niña increases the severity and the probability of diseases, such as coffee rust (Avelino et al., 2015). Thus, at least in principle, La Niña can be more harmful than El Niño, whose effects are generally beneficial for Colombian coffee production (Café de Colombia, 2014). In particular, the response of the price of Colombian Arabica coffee to La Niña (El Niño) shocks is positive (negative) and statistically significant for almost a year. Similarly, Ubilava $(2012,2018)$ shows that the response to ENSO shocks depends on the variety of coffee and ENSO phases. Although the results in these studies do not contradict our findings, the methodology differs. Ubilava $(2012,2018)$ focuses on the nominal price of coffee and implements a wide set nonlinear reduced-form models without controlling for demand and supply shocks that are also expected to affect the price of coffee. On the contrary, our model is structural, focuses on the real price of Colombian coffee, allows for both demand- and supply-side innovations, but cannot accommodate asymmetries or nonlinearities in the response to positive and negative ENSO shocks. $^{11}$

\subsubsection{Impulse-responses for the Colombian coffee market}

We now concentrate on the coffee market block of the structural VAR (i.e., the last three equations of system 3).

A negative shock to Colombian coffee supply causes an immediate, abrupt decline in Colombian coffee production, followed by a rebound. The drop is permanent and the IRF remains negative and statistically significant at the $68 \%$ confidence level for almost two years. Moreover, an unexpected supply disruption generates a permanent increase in the real price of Colombian coffee, which is statistically significant at the $68 \%$ confidence level. This shock also causes a fall in Colombian exports, which is long lived and statistically significant at the $95 \%$ confidence level.

Shocks arising in the world coffee market do not affect Colombian production, but cause a permanent increase in the real price of Colombian coffee. There is evidence of overshooting in the real price response. The IRF peaks after a quarter, then it gradually declines, while remaining statistically significant at the $95 \%$ confidence level. Note that this behavior is rather different from the dynamics of the response of the Colombian price of coffee to a negative shock to Colombian coffee supply. In that case, there is no overshooting: the IRF builds up gradually and peaks 15 months after the shock. The bottom panel in the second column of Fig. 3 shows that Colombian coffee exports experience an immediate, but very short-lived, increase in response to a price boosting effect originating in the world coffee market.

The response of Colombian coffee production to a Colombian export policy shock is never statistically distinguishable from zero. This is due to the fact that Colombian coffee production cannot be modified in the short run. This shock also generates a very small transitory increase in the real price of Colombian coffee, that is never statistically distinguishable from zero at the $95 \%$ confidence level. Finally, Colombian export policy interventions cause an immediate increase in exports, followed by a partial reversal. All in all, this behavior is consistent with the notion that small countries cannot influence the international price of their exports, which instead is mainly determined by events within the world market.

\subsection{Forecast error variance decomposition}

Table 1 shows the percentage contributions of shocks to ENSO, Colombian supply, shocks arising in the world coffee

\footnotetext{
${ }^{11}$ Ubilava (2018) finds evidence of asymmetries and nonlinearities in the response of Arabica coffee price, although in table 2 he shows that, for Arabica prices, the preferred model is a (linear and symmetric) autoregressive distributed lag. This model, which excludes exports and production, is basically a bivariate version of our reduced-form model.
} 
Table 1

Percentage contribution of each shock to the variability of Colombian coffee production, real price, and exports

\begin{tabular}{|c|c|c|c|c|}
\hline \multicolumn{5}{|c|}{ Panel (a) Variance decomposition of Colombian coffee production $\left(\Delta \operatorname{prod}_{t}\right)$} \\
\hline Horizon & ENSO & Colombian coffee supply & World coffee market & Colombian export policy \\
\hline 1 & 2.18 & 97.82 & 0.00 & 0.00 \\
\hline 3 & 2.86 & 95.47 & 1.12 & 0.54 \\
\hline 12 & 6.83 & 82.67 & 5.77 & 4.73 \\
\hline 24 & 7.68 & 72.77 & 11.44 & 8.12 \\
\hline$\infty$ & 8.29 & 69.48 & 11.88 & 10.35 \\
\hline \multicolumn{5}{|c|}{ Panel (b) Variance decomposition of the real price of Colombian coffee $\left(r p c_{t}\right)$} \\
\hline Horizon & ENSO & Colombian coffee supply & World coffee market & Colombian export policy \\
\hline 1 & 0.24 & 2.75 & 97.01 & 0.00 \\
\hline 3 & 0.82 & 2.91 & 95.51 & 0.75 \\
\hline 12 & 1.72 & 6.98 & 89.77 & 1.52 \\
\hline 24 & 1.71 & 13.69 & 83.43 & 1.16 \\
\hline$\infty$ & 5.80 & 11.52 & 75.96 & 6.72 \\
\hline \multicolumn{5}{|c|}{ Panel (c) Variance decomposition of Colombian coffee exports $\left(c \exp _{t}\right)$} \\
\hline Horizon & ENSO & Colombian coffee supply & World coffee market & Colombian export policy \\
\hline 1 & 0.02 & 10.10 & 1.94 & 87.95 \\
\hline 3 & 0.22 & 17.74 & 2.94 & 79.10 \\
\hline 12 & 5.08 & 35.25 & 5.77 & 53.90 \\
\hline 24 & 13.22 & 35.36 & 5.58 & 45.83 \\
\hline$\infty$ & 12.83 & 33.91 & 10.94 & 42.32 \\
\hline
\end{tabular}

Notes: Forecast error variance decomposition (FEVD) for the growth rate of Colombian coffee production, $\Delta p r o d_{t}$, the real price of Colombian coffee, $r p c_{t}$, and Colombian coffee exports, $\operatorname{cexp}_{t}$, based on the structural VAR model described in Section 3. FEVD at horizon " $\infty$ " is approximated by FEVD at horizon 600.

market, and shocks due to Colombian exporting decisions to the overall variability of Colombian coffee production, export, and real price, based on the forecast error variance decomposition (FEVD) of our structural VAR model at 1, 3, 12, 24 months, as well in the long run (denoted as $\infty$ ). ${ }^{12}$ Over the $1990-2016$ period, the explanatory power of ENSO shocks for the Colombian coffee market is, on average, small. On impact, ENSO shocks account only for a tiny percentage of the variation in coffee production $(2.2 \%)$, exports $(0.02 \%)$, and real price $(0.2 \%)$. In the long run, the explanatory power of ENSO shocks for production and price rises to $8.3 \%$ and $5.8 \%$, respectively.

Focusing on Panel (b) of Table 1, shocks arising in the world coffee market explain, on impact, $97 \%$ of the variation in the real price of Colombian coffee, while innovations to Colombian coffee supply account only for $2.8 \%$. In the long run, shocks to Colombian coffee supply and Colombian export interventions gain importance and explain $11.5 \%$ and $6.7 \%$ of the variation of the real price of Colombian coffee. The explanatory power of shocks from the world coffee market remains high and is equal to $76 \%$.

To sum up, the limited explanatory power of ENSO for coffee production, coupled with the fact that innovations from the world market for coffee seem more important than the supplyside shocks within the domestic coffee market, helps explaining why there is only a mild response of the real price of Colombian coffee to ENSO anomalies.

\footnotetext{
12 The long-run contribution of each shocks is approximated by computing the FEVD at horizon 600 (i.e., 50 years from the shock).
}

\section{Discussion and conclusions}

Climatological models can predict ENSO anomalies up to two years in advance (Chen et al., 2004), hence their forecasts can be used to optimize the response of policy authorities and coffee industry stakeholders to El Niño and La Niña. However, optimal policy responses to extreme weather events requires not only accurate climatological models, but also a deep understanding of the propagation mechanisms through which ENSO shocks influence the economic variables of interest. Our structural econometric model is a first step in this direction, as it provides an interpretation of the causes of different shocks to the price of coffee in Colombia. As a consequence, we can assess the impacts of ENSO shocks on the Colombian coffee industry while controlling for shocks arising in the Colombian as well as in the world coffee markets. We have shown that the overall impact of ENSO shocks on the price of Colombian coffee is small and that, both in the short run and in the long run, shocks to the international demand for Colombian coffee have more explanatory power than domestic supply-side shocks hitting the Colombian coffee industry.

Our article is novel for several respects. First, our approach is new with respect to the strand of the literature that has identified a feedback between shocks to the price of coffee and macroeconomic aggregates. This literature, differently from our article, focuses only on exogenous supply shocks (Dube and Vargas, 2013; Miller and Urdinola, 2010), does not distinguish supplyside from demand-side coffee price shocks (Otero, 2001; Raju 
and Melo, 2003), and considers the price of coffee as exogenous with respect to Colombian macroeconomic variables (Edwards, 1984). ${ }^{13}$

A second distinguishing feature of this study is that it uses monthly data. On the contrary, most of the previous analyses of the linkages between weather shocks and macroeconomic variables rely on data aggregated at annual or quarterly frequency to match the ENSO proxies with the available measures of aggregate economic activity (see Berry and Okulicz-Kozaryn, 2008; Cashin et al., 2017, and references therein). This approach is subject to the so-called "temporal aggregation bias," that is likely to affect both parameter estimates and hypothesis testing. This specification error arises when economic agents make decisions at fixed intervals of time that are more recurrent than the sampling frequency of the data (Christiano and Eichenbaum, 1987).

A third characteristic of our article is to provide an in-depth analysis for a single country and a specific commodity. Focusing on Colombia, rather than looking directly at the world coffee market and at global price indicators made available by the International Coffee Organization or futures prices, facilitates the identification of the economic effects of ENSO. With this respect, in presence of linkages between global and domestic prices that are often weak, the transmission of any production shortfall caused by ENSO anomalies from the local to the world price of a commodity might involve long delays (World Bank, 2015), making the study of the world coffee market less informative. Moreover, the analysis of a single country is preferable because the weather effects of El Niño and La Niña are highly heterogeneous across world regions (see, e.g., Davey et al., 2014; World Meteorological Organization, 2014). A similar behavior characterizes the response of macroeconomic variables and commodity prices to ENSO anomalies (Cashin et al., 2017; Iizumi et al., 2014). It is worth pointing out that coffee is a commodity with its own peculiarities. For example, El Niño often creates favorable conditions for the production of Arabica varieties, mainly grown in South America, while it leads to decrease the production of Robusta, which is concentrated in Southeast Asia (Ubilava, 2012, 2018). If the analysis of the coffee market is confined to the world level, production shortfalls for Robusta coffee can be offset by the beneficial impacts of El Niño on Arabica production. Therefore, looking at the coffee price from a global perspective without allowing for spillover effects, which can be accounted for by country-specific analyses, would lead to information losses and biased estimates of the effects of ENSO shocks.

From the point of view of macroeconomic policy, our results suggest that a given coffee price shock can have beneficial, detrimental, or negligible effects on the Colombian economy, depending on its underlying causes. For instance, a price increase due the outbreak of La Niña impacts the Colombian

\footnotetext{
${ }^{13}$ Whether the novelty of our approach translates into a better description of the propagation mechanism of commodity price shocks to the Colombian economy is a topic for future research.
}

economy differently from a price shock due to an export boom. Thus, policy responses to coffee price shocks should be carefully designed in order to take the causes of each shock into consideration (Edwards, 1984; Otero, 2001; Raju and Melo, 2003).

Our results are also relevant for designing more accurate agricultural and environmental policies. During El Niño and La Niña, the occurrence of floods, droughts, tornadoes, hail storms, and other natural disasters becomes more predictable (Allen et al., 2015; World Meteorological Organization, 2014). Colombian authorities should exploit these forecasts to implement prevention programs and strengthen communities' resilience to extreme weather events, so as to reduce their socioeconomic impacts (Oxfam, 2016). Incorporating ENSO predictions into early warning systems can save lives, reduce economic losses, and boost the benefits of ENSO when it has positive economic effects (Iizumi et al., 2014; Sun et al., 2006). ENSO forecasts can also be fruitfully used to design, implement, and improve agricultural insurance schemes (Nadolnyak et al., 2008; Tack and Ubilava, 2013, 2015). As noted before, however, the usefulness of ENSO forecasts critically depends on the understanding of the propagation mechanism of weather shocks. Our structural econometric model might be used, in combination with ENSO forecasts, by policy makers to manage the impacts of weather shocks on the Colombian coffee market.

A specific policy aspect that is related to our results is adaptation to climate change. ${ }^{14}$ We show that coffee price and production exhibit only a mild reaction to El Niño and La Niña, whereas climate change is expected to increase the frequency and intensity of both ENSO phases (Cai et al., 2014). To the extent that coffee price shocks due to extreme weather events will be experienced more often in Colombia and in other producing countries, the identification of the causes of price shocks will be crucial for stabilizing the price of coffee. A stabilization of the price of coffee might be required not only when La Niña affects Colombian internal coffee production, but also when extreme weather events affect other major producers leading to a shock to the precautionary demand for coffee. In both situations, the predictions from our model can be used to tailor specific economic actions, such as more effective stockpiling management, aimed at contrasting the undesired effects of shocks to the price of coffee, at least in the short run.

\section{Acknowledgments}

We thank the editor Ashok Mishra and four referees for insightful comments. We also thank seminar participants at

\footnotetext{
${ }^{14}$ Coffee is particularly sensitive to climate change, since even a small change in temperature can severely alter yield, flavor, and aroma. Moreover, increasing minimum growing temperatures, changes in rainfall patterns, and rising pest and disease incidence are already affecting coffee producing countries (The Climate Institute, 2016). Climate change is expected to have the global area suitable for coffee production by 2050 (Bunn et al., 2014). In Colombia, if no adaptation measures are taken, $80 \%$ of crops would be impacted by climate change, with detrimental effects for its economy (Ramirez-Villegas et al., 2012).
} 
the Euro-Mediterranean Center on Climate Change, Bologna, the University of Milan, the University of Milan-Bicocca, and the Fondazione Eni Enrico Mattei, Milan, Italy. The first author gratefully acknowledges financial support from the Italian Ministry of Education, University and Research [MIUR, PRIN 2010-2011, n. 2010S2LHSE-001] and from the Euro-Mediterranean Center on Climate Change, Bologna, Italy.

\section{References}

Allen, J.T., Tippett, M.K., Sobel, A.H., 2015. Influence of the El Niño/Southern Oscillation on tornado and hail frequency in the United States. Nat. Geosci. 8(4), 278-283.

Amisano, G., Giannini, C., 1997. Topics in Structural VAR Econometrics, 2nd edition. Springer-Verlag, Berlin.

Andalón, M., Pedro Azevedo, J., Rodríguez-Castelán, C., Sanfelice, V., Valderrama-González, D., 2016. Weather shocks and health at birth in Colombia. World Dev. 82, 69-82.

Avelino, J., Cristancho, M., Georgiou, S., Imbach, P., Aguilar, L., Bornemann, G., Läderach, P., Anzueto, F., Hruska, A.J., Morales, C., 2015. The coffee rust crises in Colombia and Central America (2008-2013): Impacts, plausible causes and proposed solutions. Food Secur. 7(2), 303-321.

Bauer, D., Maynard, A., 2012. Persistence-robust surplus-lag Granger causality testing. J. Econometrics 169(2), 293-300.

Berry, B.J.L., Okulicz-Kozaryn, A., 2008. Are there ENSO signals in the macroeconomy? Ecol. Econ. 64(3), 625-633.

Brunner, A.D., 2002. El Niño and world primary commodity prices: Warm water or hot air? Rev. Econ. Stat. 84(1), 176-183.

Bunn, C., Läderach, P., Rivera, O.O., Kirschke, D., 2014. A bitter cup: Climate change profile of global production of Arabica and Robusta coffee. Clim. Change 129(1-2), 89-101.

Café de Colombia, 2014. How El Niño \& La Niña affect production of Café de Colombia. Accessed October 2017, available at http://www.cafedecolombia.com.

Café de Colombia, 2017. Our coffee regions. Accessed October 2017, available at http://www.cafedecolombia.com.

Cai, W., Borlace, S., Lengaigne, M., van Rensch, P., Collins, M., Vecchi, G., Timmermann, A., Santoso, A., McPhaden, M.J., Wu, L., England, M.H., Wang, G., Guilyardi, E., Jin, F.-F., 2014. Increasing frequency of extreme El Niño events due to greenhouse warming. Nat. Clim. Change 4(2), 111-116.

Cárdenas, M., 1994. Stabilization and redistribution of coffee revenues: A political economy model of commodity marketing boards. J. Dev. Econ. 44(2), 351-380.

Cashin, P., Mohaddes, K., Raissi, M., 2017. Fair weather or foul? The macroeconomic effects of El Niño. J. Int. Econ. 106, 37-54.

Cavanagh, C.L., Elliott, G., Stock, J.H., 1995. Inference in models with nearly integrated regressors. Econ. Theory 11(5), 1131-1147.

Chen, D., Cane, M.A., Kaplan, A., Zebiak, S.E., Huang, D., 2004. Predictability of El Niño over the past 148 years. Nature 428(6984), 733-736.

Christiano, L.J., Eichenbaum, M., 1987. Temporal aggregation and structural inference in macroeconomics. Carnegie-Rochester Conf. Ser. Public Policy $26,63-130$.

Cochrane, J.H., 1991. A critique of the application of unit root tests. J. Econ. Dyn. Control 15(2), 275-284.

Cushman, D.O., Zha, T., 1997. Identifying monetary policy in a small open economy under flexible exchange rates. J. Monetary Econ. 39(3), 433-448.

Davey, M., Brookshaw, A., Ineson, S., 2014. The probability of the impact of ENSO on precipitation and near-surface temperature. Clim. Risk Manag. 1, $5-24$.

Daviron, D., Ponte, S., 2005. The Coffee Paradox: Global Markets, Commodity Trade and the Elusive Promise of Development. Zed Books, London.
Dell, M., Jones, B.F., Olken, B.A., 2012. Temperature shocks and economic growth: Evidence from the last half century. Am. Econ. J. Macroecon. 4(3), 66-95.

Dell, M., Jones, B.F., Olken, B.A., 2014. What do we learn from the weather? The new climate-economy literature. J. Econ. Literature 52(3), 740-798.

Dube, O., Vargas, J.F., 2013. Commodity price shocks and civil conflict: Evidence from Colombia. Rev. Econ. Stud. 80(4), 1384-1421.

Edwards, S., 1984. Coffee, money and inflation in Colombia. World Dev. 12(1112), 1107-1117.

Elliott, G., 1998. On the robustness of cointegration methods when regressors almost have unit roots. Econometrica 66(1), 149-158.

Erten, B., Ocampo, J.A., 2013. Super cycles of commodity prices since the mid-Nineteenth century. World Dev. 44(C), 14-30.

Ghoshray, A., 2010. The extent of the world coffee market. Bulletin Econ. Res. 62(1), 97-107.

Gonçalves, S., Kilian, L., 2004. Bootstrapping autoregressions with conditional heteroskedasticity of unknown form. J. Econometrics 123(1), 89-120.

Gospodinov, N., Herrera, A.M., Pesavento, E., 2013. Unit roots, cointegration, and pretesting in VAR models. In: Fomby, T.B., Kilian, L., Murphy, A. (Eds.), VAR Models in Macroeconomics-New Developments and Applications: Essays in Honor of Christopher A. Sims, Vol. 32. Emerald Group Publishing Limited, Bingley, UK.

Hamilton, J.D., 1994. Time Series Analysis. Princeton University Press, Princeton.

Hamilton, J.D., Herrera, A.M., 2004. Oil shocks and aggregate macroeconomic behavior: The role of monetary policy: A comment. J. Money Credit Bank 36(2), 265-286.

Hoyos, N., Escobar, J., Restrepo, J., Arango, A., Ortiz, J., 2013. Impact of the 2010-2011 La Niña phenomenon in Colombia, South America: The human toll of an extreme weather event. Appl. Geo. 39, 16-25.

Hsiang, S.M., Meng, K.C., 2015. Tropical economics. Am. Econ. Rev. 1105(5), 257-261.

ICO, 2014. World coffee trade (1963-2013): A review of the markets, challenges and opportunities facing the sector. Report no. ICC 111-5 Rev. 1, International Coffee Organization. Accessed October 2017, available at http://www.ico.org.

Iizumi, T., Luo, J.-J., Challinor, A.J., Sakurai, G., Yokozawa, M., Sakuma, H., Brown, M.E., Yamagata, T., 2014. Impacts of El Niño Southern Oscillation on the global yields of major crops. Nat. Commun. 5(3712), 1-7.

Kilian, L., 2009. Not all oil price shocks are alike: disentangling demand and supply shocks in the crude oil market. Am. Econ. Rev. 99(3), 1053-1069.

Kilian, L., Lütkepohl, H., 2017. Structural Vector Autoregressive Analysis. Cambridge University Press, Cambridge, UK.

Mehta, A., Chavas, J.-P., 2008. Responding to the coffee crisis: What can we learn from price dynamics? J. Dev. Econ. 85(1-2), 282-311.

Miller, G., Urdinola, B.P., 2010. Cyclicality, mortality, and the value of time: the case of coffee price fluctuations and child survival in Colombia. J. Pol. Econ. 118(1), 113-155.

Nadolnyak, D., Vedenov, D., Novak, J., 2008. Information value of climatebased yield forecasts in selecting optimal crop insurance coverage. Am. J. Agric. Econ. 90(5), 1248-1255.

Osorio, N., 2002. The Global Coffee Crisis: A Threat to Sustainable Development. Submission to the World Summit on Sustainable Development, Johannesburg.

Otero, J.G., 2001. Coffee export booms and monetary disequilibrium: Some evidence for Colombia. Appl. Econ. 33(2), 267-276.

Oxfam, 2016. A preventable crisis. Briefing Note, Oxfam. Accessed October 2017, available at: https://www.oxfam.org.

Pendergrast, M., 1999. Uncommon Grounds: The History of Coffee and How It Transformed Our World. Basic Books, New York, NY.

Ponte, S., 2002. The 'Latte Revolution'? Regulation, markets and consumption in the global coffee chain. World Dev. 30(7), 1099-1122.

Poveda, G., Jaramillo, A., Gil, M.M., Quiceno, N., Mantilla, R.I., 2001. Seasonally in ENSO-related precipitation, river discharges, soil moisture, and vegetation index in Colombia. Water Resour. Res. 37(8), 2169-2178. 
Raju, S.S., Melo, A., 2003. Money, real output, and deficit effects of coffee booms in Colombia. J. Pol. Model. 25(9), 963-983.

Ramirez-Villegas, J., Salazar, M., Jarvis, A., Navarro-Racines, C.E., 2012. A way forward on adaptation to climate change in Colombian agriculture: perspectives towards 2050. Clim. Change 115(3-4), 611-628.

Sims, C.A., Stock, J.H., Watson, M.W., 1990. Inference in linear time series models with some unit roots. Econometrica 58(1), 113-144.

Sun, C.-H., Chiang, F.-S., Tsoa, E., Chen, M.-H., 2006. The effects of El Niño on the mackerel purse-seine fishery harvests in Taiwan: An analysis integrating the barometric readings and sea surface temperature. Ecol. Econ. 56(2), 268-279

Tack, J.B., Ubilava, D., 2013. The effect of El Niño Southern Oscillation on U.S. corn production and downside risk. Clim. Change 121(4), 689-700.

Tack, J.B., Ubilava, D., 2015. Climate and agricultural risk: Measuring the effect of ENSO on U.S. crop insurance. Agric. Econ. 46(2), 245-257.

Terazono, E., 2013. Brazilians smooth out Arabica price cycle. Financial Times. Accessed October 2017, available at http://www.ft.com.

The Climate Institute, 2016. A brewing storm: The climate change risks to coffee. Accessed October 2017, available at http://www.climateinstitute.org.au.

Toda, H.Y., Yamamoto, T., 1995. Statistical inference in vector autoregressions with possibly integrated processes. J. Econometrics 66(1), 225-250.

Ubilava, D., 2012. El Niño, La Niña, and world coffee price dynamics. Agric. Econ. 43(1), 17-26

Ubilava, D., 2018. The role of El Niño Southern Oscillation in commodity price movement and predictability. Am. J. Agric. Econ. 100(1), 239-263.

Vogelvang, E., 1992. Hypotheses testing concerning relationships between spot prices of various types of coffee. J. Appl. Econometrics 7(2), 191-201.

Wegmann, U., 2013. Brazilian on/off-cycle. Volcafe Insight Special. Accessed October 2017, available at http://www.volcafespecialty.com.

Wickens, M.R., Greenfield, J.N., 1973. The econometrics of agricultural supply: an application to the world coffee market. Rev. Econ. Stat. 55(4), 433-440.
World Bank, 2015. Commodity Markets Outlook. World Bank, Washington, DC.

World Meteorological Organization, 2014. El Niño/Southern Oscillation. Working paper no. 1145, Geneva, Switzerland.

\section{Supporting Information}

Additional supporting information may be found online in the Supporting Information section at the end of the article.

\section{Supporting Information}

Table A1: Descriptive statistics

Figure A1: Sea surface temperatures and Southern Oscillation Index: 1990:1-2016:5.

Figure A2: Production, export, and real price of coffee in Colombia: 1990:1-2016:5.

Figure A3: Box plots of variables per month for each month of the year.

Table C2: Test of asymmetric response to ENSO shocks Figure A4: Impulse responses to a positive ENSO shock using SOI.

Figure A5: Impulse responses to a positive ENSO shock from VAR(6) and VAR(12) models.

Figure A6: Impulse responses to a positive ENSO shock (strong exogeneity of $s s t_{t}$ ). 